\title{
ESSENTIAL ASPECTS OF THE AGRICULTURAL DEVELOPMENT AND MANAGEMENT OF PAKIHI SOILS
}

\author{
R. CAMERON and I. MORrison
}

Department of Lands and Survey, Hokitika nnd Westport

\section{A bstract}

The development of the West Coast's pakihi soils for pastoral purposes is a relatively simple process but involves several essential factors. Access, drainage, weed control and fencing must all be provided prior to oversowing of lime, fertilizer and seed. The management of pakihi soils, while essentially similar to that of alluviai or recent soil types, also has some additional problems. The most important decisions to be made are the type and breed of stock, the lambing and/or calving date, and matching the stocking rate as best as possible to the pasture growth in your area. The right decisions coupled with good pasture management will result in a productive pasture, a good stocking rate, and good returns from these stock.

\section{INTRODUCTION}

THE Department of Lands and Survey is involved in a largescale development operation on the pakihi soils of Westland, spread over several individual farm settlements. The transition from undeveloped pakihi to grass can now be made by following a formula that has been developed and refined by the Department, and the Ministry of Agriculture and Fisheries, over the last twenty years.

This paper deals with the main factors involved in the development and management of pastures on these soils.

\section{DEVELOPMENTAL}

ACCESS

Access should be planned to allow suitable subdivision for stock movement and management. This may only involve an inexpensive system of double-fenced lanes on the drier ridges. It is more common to form tracks by stripping the "topsoil" down 
to the gravel with a bulldozer although the suitability of this method is obviously limited by the depth of the pakihi. In some cases it may be necessary to form a gravelled track, but this would normally only be done where vehicle access is required across some of the deeper pakihis.

It is essential that the flow of natural water-courses and drainage channels is not impeded by access tracks, and adequate culverts must be installed, or fords constructed where there is a solid gravel base.

\section{DRAINAGE}

It is essential that a suitable drainage system be developed on the pakihi soils before pasture establishment. The type and extent of the drainage are obviously relative to the depth and type of pakihi. The drainage system must be engineered to maximize the surface run-off of rain water, which, in Westland's climate, can be substantial. Removal of water from areas of severely impeded natural drainage is also necessary.

On the shallower pakihis, the natural water-courses may be opened up using either an angle blade or a vee blade on a bulldozer. This method is the least expensive, and is effective where sufficient fall is available. However, care must be taken to minimize the restriction of lateral flow into these drains, and cuts through the spoil may be necessary.

Where the depth of the pakihi prevents the use of a bulldozer for drainage work, then a hydraulic excavator must be used. This often involves a system of secondary drains, as well as opening up the natural main water courses, and is consequently more expensive. The number and intensity of these drains required depend on the degree of wetness of the pakihi being developed.

In all cases it is essential that the main drainage system be completed prior to pasture establishment and other development work, preferably by at least one year.

\section{Gorse Control}

The most common weed that occurs on the pakihis is gorse. Its presence normally indicates a relatively dry pakihi, or one with a slightly higher natural fertility. These are often the most suitable for development. However, to develop these areas successfully, it is necessary to implement some method of gorse control, before fertilizer and lime are applied. The cheapest and most successful system used in recent years has been to aerial spray 
2,4,5-T, or Tordon 520 Brushkiller or equivalent by helicopter. The current cost (unsubsidized) of a blanket application of 22 litres/ha of Tordon 520 Brushkiller, in 400 litres/ha of water, plus an anti-drift agent using the half overlap technique, is approximately $\$ 260 / \mathrm{ha}$.

The most promising alternative technique is the use of a low ground pressure bulldozer with a blade or rootrake to windrow, or heap the surface material, including gorse, stumps and fallen timber. This operation may be done in conjunction with the drainage programme, well in advance of the grassing, and an aerial spray at a lower application rate can then be used in the autumn, prior to a spring oversow. The cost of the clearing by bulldozer can be covered by halving the application rate of Tordon 520 Brushkiller. The end result is a gorse-free, cleaned surface, ideally suited for oversowing, and in such a condition as to aid future management. In some cases the regrowth of the gorse after rootraking or clearing with the bulldozer may not warrant a blanket application of weedicide.

Burning prior to oversowing with a follow-up spot-spraying programme is used at times on areas where the gorse infestation is slight. If a successful burn can be obtained, this method results in the clearing of the existing vegetation, leaving an open surface for oversowing. Burning is not advisable where gorse is a major problem as it tends to encourage the germination of gorse seeds already in the ground.

Once the pasture is established, new gorse seedlings can be controlled with correct grazing management if adequate subdivision has been provided.

\section{PASTURE ESTABLISHMENT}

Pasture establishment after the preparatory development work has been completed is relatively simple. The aerial sowing of lime, fertilizer and seed is normally done in the spring (October) with a second application. of fertilizer in February. However, successful oversowing can be achieved in the autumn, with the second dressing of fertilizer in the following spring.

The rates and types of materials required in the first application are a minimum of 3.75 tonnes/ha of lime, and $500 \mathrm{~kg} / \mathrm{ha}$ of a special mix fertilizer known as the "Westland Pakihi Development Mix" (consisting of serpentine superphosphate plus copper sulphate, boron, cobalt sulphate and sodium molybdate) . Optimum rates are 5 tonnes/ha of lime and $750 \mathrm{~kg} / \mathrm{ha}$ of the 
Westland Mix. The second application of fertilizer required is $500 \mathrm{~kg} / \mathrm{ha}$ of $22 \%$ potassic sulphurized superphosphate, to be applied within six months of the first application.

The seed mixtures used have been modified over the years as indicated by trial work and the availability of new cultivars, and vary for sheep and cattle pastures,

For predominantly sheep-grazed pastures, the recommended seed mixture is $20 \mathrm{~kg} / \mathrm{ha}$ of Nui ryegrass and $3 \mathrm{~kg} / \mathrm{ha}$ (bare seed weight) of Huia white clover. It is essential that all,clover seed is inoculated and pelleted. Turoa red clover at $1 \mathrm{~kg} / \mathrm{ha}$ (bare seed weight) is optional, but can result in an excess of feed in the first season, which may not be fully utilized and may lead to infertility problems in ewes.

For pastures predominantly cattle grazed, the recommended seed mixture is $10 \mathrm{~kg} / \mathrm{ha}$ Nui ryegrass, $5 \mathrm{~kg}$ / ha Manawa ryegrass with $3 \mathrm{~kg} / \mathrm{ha}$ (bare seed) Huia white clover and $1 \mathrm{~kg} / \mathrm{ha}$ (bare seed) Turoa red clover (both clovers innoculated and pelleted), plus an optional $3 \mathrm{~kg} / \mathrm{ha}$ of Apanui cocksfoot and $2 \mathrm{~kg} / \mathrm{ha}$ of timothy. If the latter two are not included, they should be replaced by an equivalent amount of ryegrass. Turoa may lead to bloat problems, and may be deleted.

\section{FENCING}

Provision of adequate subdivision before any seed is sown is probably the most important factor in the development of pakihi soils. Without adequate stock control, good pasture management and the successful development of pakihi are impossible.

The intensity of the subdivision is determined by the size of the development operation and the stock available. Electric fencing for internal subdivision provides some flexibility and is also a relatively inexpensive alternative to traditional fencing.

\section{MANAGEMENT}

Stocking Policy

Our experience of managing new pastures on pakihi soils has resulted in two fairly definite policies - first, that sheep are far more suitable for the initial grazings, preferably until the pasture is at least twelve months old, and, secondly, Perendales are better suited than Romneys, as they are hardier, tolerate wet conditions better, give a good lambing percentage, fatten well, and have a low death rate. Their one negative character is a lower wool weight, which is made up a little in price. 
Young cattle can also be grazed on the pastures, but it is usually difficult to obtain the desirable grazing pressures without some form of pugging.

\section{Grazing Management}

Rotational grazing is recommended for at least the first 12 months of the new pasture. Whereas Perendale ewes are usually set-stocked in the spring for lambing, the ewe hoggets can be rotationally grazed during this period. Pasture production is obvously limited during the first year, but, if the establishment has been successful and management good, the pasture should be approaching a high level of production by the end of the second year. Grazing pressures should also be increasing, so that from the third year on the desirable grazing pressure of 300 to 500 $\mathrm{SU} /$ ha/day for a maximum of three days should be attainable.

A good supply of water is essential if the optimum grazing pressures and production are to be achieved. This has to be provided if fresh running water is not available.

There are three main benefits of rotational grazing. The pasture is grazed off evenly (without over- or under-grazing); the ground is consolidated by the sheep's hooves resultng in a good even pasture, very little pugging damage, and a faster run-off of water in heavy rains; dung and urine are spread more evenly over the whole paddock. This activates the fertility cycle which is so important on these low fertility soils. It is the cycling of nutrients, in particular phosphate, sulphate, potassium and nitrogen, that maintains a healthy, productive sward and therefore enables optimum stocking rates to be achieved.

\section{Pasture Growth Curve}

The average seasonal distribution of pasture growth rates, as measured at Bald Hill 1967-73 by Radcliffe, shows that most of the pasture growth occurs from October to March or April, with November to January being the main growth period. This results in an excess of pasture in the summer period and/or a deficit in the winter, or early spring, depending on stocking rates. If the stocking rate is too low and the excess growth in summer is not utilized, then autumn growth will be reduced, thus affecting the amount of feed available in the winter. Conversely, if the stocking rate is too high, the late winter/early spring period could present problems. Thus it is important to attain a stocking rate that best meets the needs of both winter 
and summer periods. We have found that higher stocking rates in winter are attainable with sheep, which goes some way to controlling summer surpluses. Other alternatives are making hay and/or silage, or buying store stock where practicable.

\section{Lambing and Calving Dates}

At optimum stocking rates, the choice of lambing date is important. If it is too early, a feed deficiency could result with consequent effects on ewe and lamb. As the spring growth is not really significant until early October, lambing should be delayed until late September/early October to take advantage of this growth.

The calving date in beef herds is usually early to mid-September so that calves are a reasonable size for the autumn calf sales. This may be false economics, perhaps a matter of pride rather than a real price advantage at the sales. In dairy herds, a calving date could be chosen that coincides better with spring growth. However, as the economics of dairying on a per hectare basis are usually far more favourable than beef or sheep, the strategic use of artificial nitrogenous fetilizers is probably justified.

\section{Maintenance Lime and Fertilizer}

The recommended maintenance lime requirement is $2.5 \mathrm{t} / \mathrm{ha}$, applied every three years. For sheep and beef farms, the fertilizer maintenance recommended is $500 \mathrm{~kg} / \mathrm{ha}$ of $22 \%$ potassic sulphur superphosphate, applied in one dressing in September. For dairy farms, an additional $250 \mathrm{~kg} / \mathrm{ha}$ of the same fertilizer should be applied in January or February.

\section{WeEd Control}

The two weeds of major concern are gorse and rushes. Where required, spot spraying of gorse with $2,4,5-\mathrm{T}$ is practised. However, the gorse regrowth can be controlled with effective rotational grazing.

Rush contol should not be a problem if pastures are correctly grazed from the time of establishment. However, where rushes have become a problem, a combination of mowing and rotational grazing, partcularly with Perendales, is effective. Rotational grazing or mob-stocking with cattle can also be effective, but pugging damage often results, which can aggravate the situation. Spraying with 2,4-D or glyphosate is sometimes the best solution on dairy farms. 
DRAINING

Once established, the evapotranspiration of a vigorously growing pasture and treading pressure of stock, in particular sheep, will consolidate the soil and the smaller, natural drainage channels will become evident. Many of these will need to be opened up, and, depending on the size of the drain required, can be dug with a back-actor, snow-plough or V-blade, or a spinner drainer.

\section{FUTURE}

Good management of pakihi soils will result in carrying capacities in excess of $12 \mathrm{SU} / \mathrm{ha}$. At this stocking rate, the economic success of farming pakihi will be assured.

However, under average management, the economics will hinge on two aspects. First, preparation of the surface, where possible, for ground spreading of fertilizer and lime. Suitable machinery will no doubt be developed for this operation. This machinery may consist of wide, rubber-tyred vehicles for crossing consolidated, timberless ground, or tracked machines with blowers for timbered or rougher country. The second aspect is the ability to match stock demand to feed supply as best as possible, thereby keeping wintering costs to a minimum.

Looking further to the future, after a period of consolidation, some of the soil types will possibly be suitable for dairying. Whether or not this happens, the development and good management of pakihi soils will result in a vastly increased production, providing intangible socio-economic benefits, to the West Coast. 